\title{
The Role of Human Papilloma Virus in the Development of Oral Squamous Cell Carcinoma in Pakistani Population
}

\author{
Joharia Azhar ${ }^{1 *}$, Sadia Salahuddin ${ }^{1}$ and Ishtiaq Qadri ${ }^{2}$ \\ ${ }^{1}$ Department of Diagnostic Oral Sciences, Princess Nourah Bint Abdulrehman University, Riyadh, Saudi Arabia \\ ${ }^{2}$ King Abdul Aziz University, Saudi Arabia
}

Submission: November 13, 2018; Published: November 29, 2018

*Corresponding author: Joharia Azhar, Associate Professor and Consultant Oral Pathologist, Chair PBL unit, Department of Diagnostic Oral Sciences, Princess Nourah Bint Abdulrehman University, Riyadh, KSA, Saudi Arabia

\begin{abstract}
Oral cancer is one of the most prevalent cancers in Pakistan and the Pakistani population seems to be especially susceptible to the development of oral cancer. Human Papilloma virus has already been implicated in the etiology of cervical cancer, and strong evidence suggests its close association with the oral cancer. The aim of our study was to define the role of Human Papilloma virus in the development of oral squamous cell carcinoma patients in Pakistani population. Ninety-five patients with oral squamous cell carcinoma samples were recruited for this study. HPV infectivity was determined histopathological by observing Koilocytosis and molecularly by conducting PCR using HPV consensus primers. HPV genotyping was then carried out using the HPV genotyping PCR assay technique. The results of HPV prevalence and genotyping were evaluated in relation to various clinico-pathalogical parameters Statistical Package for the utilizing social sciences version 12.0 for windows (SPSS Inc, Chicago, IL). HPV was detected in $78 \%$ cases, out of whom $74 \%$ were associated with HPV16, $4 \%$ with HPV 18, $15 \%$ were co infected with HPV 16 and 18, and 7\% were positive for HPV by the general primer and could not be type specified. This study finds a significant association between type $16 \mathrm{HPV}$ prevalence and oral squamous cell carcinoma with male patients showing high co-relations.
\end{abstract}

Keywords: Oral cancer; Human papilloma virus HPV; Genotyping; Polymerase chain reaction PCR; Oral squamous cell carcinoma OSCC; Histopathology; Koilocytes; Oncogenic virus

Abbreviations: GP: General Primer for L1 HPV; TS: Type-Specific primers for L1 HPV; BG: primers for $\beta$-Globin gene; BP: Base Pairs

\section{Introduction}

Pakistan is one of the high-risk countries for oral cancer development, where oral cancer is the most prevalent cancer in men and may account for up to $30 \%$ of all new cases of cancer per year, compared to $3 \%$ in the UK and $6 \%$ in France [1]. Many known etiological factors for oral cancer development, like Pan, Betel Nut, Areca nuts and smoking are very commonly used in Pakistan, however not all the people exposed to these factors develop cancer. Furthermore, many patients not exposed to any of these factors develop cancer. This indicates the presence of additional risk factors, including Human Papilloma Virus that can make these people more susceptible to cancer.

More recently research has associated certain genotypes of HPV to the Papillary SCC of the Head and Neck [2], to OSCC [3], to the upper aerodigestive tract tumours $[4,5]$, not to mention malignant and pre-malignant lesions of the uterine cervix [6], ulva [7], penis [8], and conjunctiva [9]. However, the exact mechanism of the interaction of HPV and the significance of its presence in the development of carcinogenesis is still not clear4. Discrepancies in the prevalence of HPV in OSCC have been observed, geographically, in the more recent studies, creating further confusion4. Certain studies investigating role of HPV in PSCC, a subset of SCC have reported prevalence of transcriptionally active HPV in almost $54 \%$ of cases2, while some others report a failure of PCR studies to show transcriptionally active HPV [10].

The aim of this study was to detect the prevalence of HPV in the OSCC patients of the Pakistani origin and to determine the most prevalent genotype of HPV associated with OSCC in Pakistani patients.

\section{Methods and Materials}

\section{FFPE tissue samples of oral squamous cell carcinoma}

This study is based on samples retrospectively collected from 72 different oral cancer patients diagnosed with oral squamous cell carcinoma OSCC during the period of 2005-2010. Inclusion criteria were complete clinicopathologic data and availability of enough paraffin- embedded tumour material. The clinicopathological data consisted of age, gender, geographical location of the patient, site of lesion and histopathological grade. OSCC samples were formalin fixed paraffin embedded. A total of 72 blocks of paraffin-embedded tissue including samples diagnosed 
as oral squamous cell carcinoma stages I, II and III, verrocus carcinoma, focal dysplasias, and fibroepithelial hyperplasias were retrieved from the archive of Pakistan Institute of Medical sciences (PIMS), and KRL hospital Islamabad, from year 2005 to 2010. Samples were taken from different lesion sites including maxilla, mandible, tongue, floor of the mouth, labial and buccal mucosa, naso-pharynx and vocal cords.

\section{Fresh tissue samples of oral squamous cell carcinoma}

The second group of samples consisted of 23 fresh samples in which around 6 were fresh unfixed biopsy specimen while 17 were fresh endoscopic samples obtained from ENT department $\mathrm{CMH}$, Rawalpindi. The samples collected were stored at $4{ }^{\circ} \mathrm{C}$ in Diagnostic Laboratory, NCVI, NUST, Islamabad until they were ready for further processing.

\section{Histopathological examination}

Representative tissue sections of $3 \mu \mathrm{m}$ thickness were cut on a microtome and the slides were kept at $60^{\circ} \mathrm{C}$ for 30 minutes. Sections were stained with Harri's Haematoxylin and observed under the microscope. Histopathological diagnosis was confirmed and histopathological evaluation for staging was carried out.

\section{Genomic DNA extraction}

Genomic DNA Extraction from Formalin Fixed Paraffin Embedded (FFPE) Tissue Biopsies: Using a standard microtome with disposable blades, sections of $20 \mu \mathrm{m}$ thicknesses was obtained from the block with the microtome blade properly cleaned in between every sample to avoid contamination. Each of the sections was placed in a $1.5 \mathrm{ml}$ eppendorf tube. Blocks with the similar amount of tissue and the same section thickness were used for all DNA isolation methods. DNA was extracted from formalinfixed paraffin blocks by Xylene-ethanol method. Cut section from each case was deparaffinized and DNA was extracted by adding one $\mathrm{ml}$ of xylene to each $20 \mu \mathrm{m}$ section. Tubes were agitated for $30 \mathrm{~min}$ at room temperature and spun at $13000 \mathrm{rpm}$ for $10 \mathrm{~min}$. The supernatant was removed carefully, one $\mathrm{ml}$ fresher xylene was added, and the step repeated. Two identical washes with $100 \%$ ethanol were performed followed by spinning at $13000 \mathrm{rpm}$ for 10 minutes. Tissue pellets were air dried at $37^{\circ} \mathrm{C}$. Tissue digestion was done by adding $400 \mu \mathrm{l}$ of the tissue digestion buffer (Tris-Cl $(100 \mathrm{mM}, \mathrm{pH}=7.5)$, Tween-20 $(0.05 \%)$ ) to each tube containing tissue pellet. Then, $20 \mu \mathrm{l}$ of $500 \mu \mathrm{g} / \mathrm{ml}$ of Proteinase K (Invitrogen) was added, agitated, and tubes were left overnight at $56{ }^{\circ} \mathrm{C}$ in water-bath. Digestion buffer was inactivated by heating for 10 minutes in boiling water and the cell debri was spun down. The supernatant containing the DNA was transferred to a new DNA tube and was used directly in PCR. The extracted DNA was frozen at $-20^{\circ} \mathrm{C}$ until use.

Genomic DNA extraction from fresh biopsy/ endoscopy tissue samples: Fresh biopsy specimen was homogenized in glass homogenizer. Homogenized tissue was then placed in $1.5 \mathrm{ml}$ eppendorf tube to which $400 \mu \mathrm{l}$ of digestion buffer [Tris- $\mathrm{Cl}(100$ $\mathrm{mM}, \mathrm{pH}=7.5)$, Tween-20 (0.05\%)] was added. Then $5 \mu \mathrm{l}$ of $20 \mu \mathrm{g} /$ $\mu$ Proteinase K (Invitrogen) was added to it, and tubes left to agitate overnight at $56{ }^{\circ} \mathrm{C}$ in a water-bath. Digestion buffer was inactivated by heating for 10 minutes in boiling water and the cell debri was spun down. The supernatant containing the DNA was transferred to a new DNA tube and was used directly in PCR. The extracted DNA was frozen at $-20{ }^{\circ} \mathrm{C}$ until use.

\section{Testing for DNA quality and quantity}

Table 1: Primers used for PCR amplification.

\begin{tabular}{|c|c|c|c|c|}
\hline Sequence & Target Gene & Annealing temperature $\left({ }^{\circ} \mathrm{C}\right)$ & Amplimer Length(bp) & \\
\hline BG-F & GTGCTCGGTGCCTTTAGTGA & \multirow{2}{*}{$\beta$-globin } & \multirow{2}{*}{56} & \multirow{2}{*}{130} \\
\hline BG-R & CAGGGTGAGTCTATGGGACG & & & \\
\hline GP5 & TTTGTTACTGTGGTAGATAC & \multirow{2}{*}{ L1 } & \multirow{2}{*}{45} & \multirow{2}{*}{155} \\
\hline GP6 & GAAAAATAAACTGTAAATCA & & & \\
\hline TS16F & GGTCGGTGGACCGGTCGATG & \multirow{2}{*}{ E6 } & \multirow{2}{*}{54} & \multirow{2}{*}{96} \\
\hline TS16R & GCAATGTAGGTGTATCTCCA & & & \\
\hline $\mathrm{TS} 18 \mathrm{~F}$ & CCTTGGACGTAAATTTTTGG & \multirow{2}{*}{ L1 type18 } & \multirow{2}{*}{58} & \multirow{2}{*}{160} \\
\hline TS18R & CACGCACACGCTTGGCAGGT & & & \\
\hline
\end{tabular}

DNA concentration was measured by spectrophotometer (Eppendorf Biophotometer plus, Germany). Optical density was measured at 260 and $280 \mathrm{~nm}$. The ratio of absorbance at $260 / 280$ was used to determine quality of DNA. A ratio above 1.0 was inacceptable range. Successful DNA extraction was assessed by PCR amplification of a $130 \mathrm{bp}$ fragment of the $\beta$-globin gene. Sequences of primers are given in Table 1.

\section{HPV detection PCR}

HPV detection PCR was performed using primers published elsewhere (Baay MF, et al, 1996). The sequence for the primers
GP5 and GP 6 is given in the Table 1 along with the length of respective amplimer and target gene. Polymerase chain reaction round was performed in $0.2 \mathrm{ml}$ tubes (Axygen, USA) with $5 \mu \mathrm{l}$ of sample DNA dilution in $25 \mu \mathrm{l}$ of reaction mixture, using $0.4 \mu \mathrm{l}$ of MBI Fermentas, UK Taq polymerase $(2 \mathrm{U} / \mu \mathrm{l}), 2.4 \mu \mathrm{l} \operatorname{MgCl} 2(25$ $\mathrm{mM}), 3.0 \mu \mathrm{l}$ of (10X) PCR Buffer, $1.0 \mu \mathrm{l}$ DNTPs $(2 \mathrm{mM}), 2.0 \mu \mathrm{l}$ each of both Forward and reverse primers $(10 \mathrm{pmol} / \mu \mathrm{l})$ and $9.2 \mu \mathrm{l} \mathrm{dH} 20$ (nuclease free). The PCR was performed on Applied Biosystem (ABI Veriti, Singapore) 96 well thermocycler. The PCR thermal profile was $94{ }^{\circ} \mathrm{C}$ for 4 minutes, and 35 cycles of $94{ }^{\circ} \mathrm{C}$ for 30 
seconds, $45^{\circ} \mathrm{C}$ for 30 seconds, $72{ }^{\circ} \mathrm{C}$ for 30 seconds, and 7 minutes final extension at $72^{\circ} \mathrm{C}$.

\section{HPV 16 and 18 type specific PCR}

All samples were further genotyped for type 16 and type 18, by carrying out the type specific PCR published elsewhere [11]. The sequence for the primers for type 16 and 18 are given in the Table 1 , along with the length of respective amplimer and target gene. Polymerase chain reaction round was performed in $0.2 \mathrm{ml}$ tubes (Axygen, USA) with $5 \mu$ l of sample DNA dilution in $20 \mu \mathrm{l}$ of reaction mixture for both reactions, using $0.4 \mu \mathrm{l}$ of MBI Fermentas, UK Taq polymerase, $2.3 \mu \mathrm{l} \mathrm{MgCl}_{2}(25 \mathrm{mM}), 2.0 \mu \mathrm{l}$ of (10X) PCR Buffer, $1.0 \mu \mathrm{l}$ DNTPs $(2 \mathrm{mM}), 1.0 \mu \mathrm{l}$ each of both Forward and reverse primers $(10 \mathrm{pmol} / \mu \mathrm{l}$ ) and $7.3 \mu \mathrm{l} \mathrm{dH2O} \mathrm{(nuclease} \mathrm{free).} \mathrm{The} \mathrm{PCR} \mathrm{was}$ performed on Applied Biosystem (ABI Veriti, Singapore) 96 well thermocycler. The PCR thermal profile for both reactions was 94 ${ }^{\circ} \mathrm{C}$ for 4 minutes, and 35 cycles of $94^{\circ} \mathrm{C}$ for 30 seconds, annealing temperature for type $16 / 18$ was $54 / 61^{\circ} \mathrm{C}$ for 30 seconds, $72^{\circ} \mathrm{C}$ for 30 seconds, and 7 minutes final extension at $72{ }^{\circ} \mathrm{C}$.

\section{Statistical analysis}

Data were processed by SPSS statistical software program version 12.0. The correlations were analysed by running cross tabulation tests. Cross tabulations were analysed using chi-square test or fisher's exact test and Pearson co-relation test where applicable. P value measures the significance of an association and is significant when it is less than or equal to $5 \%(0.05)$.

\section{Results}

\section{Demographics of the study population:}

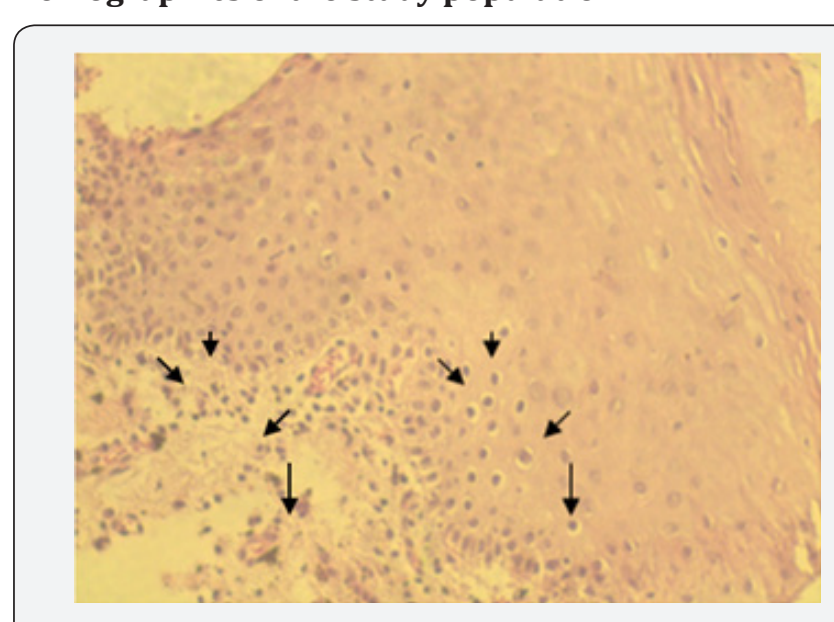

Figure 1: Photomicrograph of $\mathrm{H} \& \mathrm{E}$ stained well differentiated squamous cell carcinoma infected with HPV. The morphological signs of HPV infection in the form of koilocytotic can be seen. Koilocytes (arrow heads) are shown to be arising from the basal cells of oral epithelium and are moving towards the upper layers, as the HPV gene expression is associated with the degree of differentiation. Magnification $\times 20$.

The study population consisted of a total of 95 patients admitted to the dental ward of PIMS, Islamabad, Maxillo-facial Surgery ward of KRL hospital, Islamabad and ENT ward of CMH, Rawalpindi. The demographic parameters included in our study were age, gender, geographic location and specimen site. Patients ages ranged from 16 years to 86 (mean age $=51$ years; $\pm S D=14$ ). $87 \%$ of the patients were above 35 years of age $(n=83) .55 \%$ of the patients were males $(n=52 ; \pm S D=0.500)$ while around $45 \%$ $(\mathrm{n}=43 ; \pm \mathrm{SD}=0.500)$ were females. A total of $86 \%$ of males were $>35$ years of age $(n=45)$ and about $89 \%$ of the female patient population was $>35$ years $(\mathrm{n}=38)$. There were $80(83 \%)$ cases of squamous cell carcinoma, $3(3.2 \%)$ cases of oral submucous fibrosis which is a pre-malignant condition and 12 (13\%) cases of fibroepithelial polyps. The most common anatomic site of involvement was mandible including the tongue area with $40 \%$ $(n=38)$ of the cases occurring here. The next most common site was the nasopharynx and vocal cords with $23.2 \%(n=22)$ of the patients having carcinoma of the oral cavity that had metastasized to the neck. Around 20\% (n=19) of the cases involved either the buccal or the labial mucosa with $4 \%(n=4)$ showing gingival involvement, while maxillary and palatal involvement was found in $12.4 \%(\mathrm{n}=12)$ of the cases.

\section{Histopathology}

The histopathological evaluation was carried out and the squamous cell carcinomas were graded. We had a total of 49 (52\%) cases of well differentiated squamous cell carcinomas designated as histopathological stage I cancer. 25 (26\%) cases were of moderately differentiated squamous cell carcinoma graded as stage II cancer while $4(4 \%)$ cases were of the poorly differentiated variety graded as stage III cancer. All the samples were also observed for the presence of koilocytes (Figure 1) to determine the efficacy of morphological assays in the identification of HPV infection. Out of the 95 samples about 50 (53\%) were positive for the presence of koilocytes.

\section{Detection of HPV by GP PCR}

Out of a total of 95 oral squamous cell carcinoma samples 72 were formalin fixed and paraffin embedded, 6 were fresh biopsy specimen unfixed and 17 were endoscopic specimen. Out of these 95, $51(54 \%)$ were positive for HPV when GP PCR was done (Figure $2 \& 3$ ). However, it was observed during genotyping PCR's that some of the samples previously determined to be negative by the GP PCR were positive for type $16 \mathrm{HPV}$. Therefore, the total infected samples were calculated to be 74 (78\%) (Figure 4). The sensitivity and specificity of the GP PCR for HPV detection were also determined and was found to be $74 \%$ and $81 \%$ respectively. The following formulas were utilized to determine the sensitivity and specificity.

SENSITIVITY $=$ Those that are test positive $/$ All with disease $=74 \%$ SPECIFICITY $=$ Those that are test negative $/$ All without disease $=81 \%$

Cross tabulation analysis showed that out of 43 females 29 (67\%) were infected. Similarly, out of 52 males 45 (87\%) were infected. Sex difference among the patients was significantly corelated to HPV infectivity as determined by the Pearson chi square test $(\mathrm{P}=0.02)$. HPV was detected in $37(82 \%)$ out of 45 stage I well differentiated squamous cell carcinomas, $21(84 \%)$ out of 25 stage II moderately differentiated carcinomas, 3 (75\%) out of 4 stage III poorly differentiated carcinomas. The single sample 


\section{Advances in Dentistry \& Oral Health}

of verrocus carcinoma was positive for HPV as well as 12 (75\%) out of 16 fibro-epithelial proliferations. All in all, no significant association was found between age groups, site of involvement and histological differentiation.
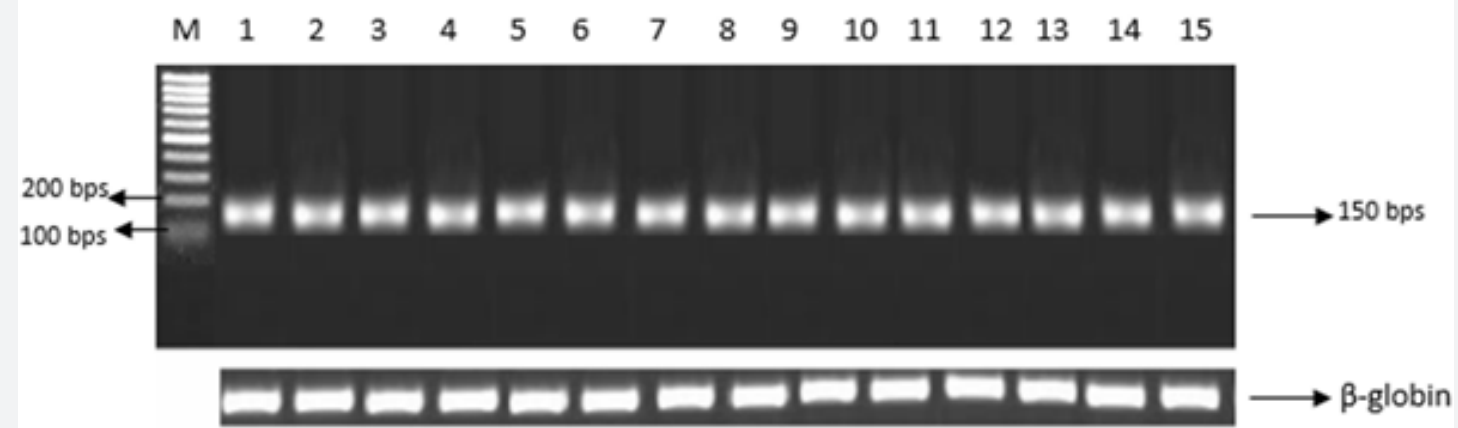

Figure 2: PCR amplification of HPV using general primers. The amplified products were separated on $2.0 \%$ agarose gel. Lane-M: $100 \mathrm{bp}$ ladder molecular size marker; Lane-1: Positive control. Lanes; 2,3,4,5,6,7,8,9,10,11,12,13,14,15: (150 bp product); $\beta$-globin gene is shown as a PCR DNA control. (Lower panel).

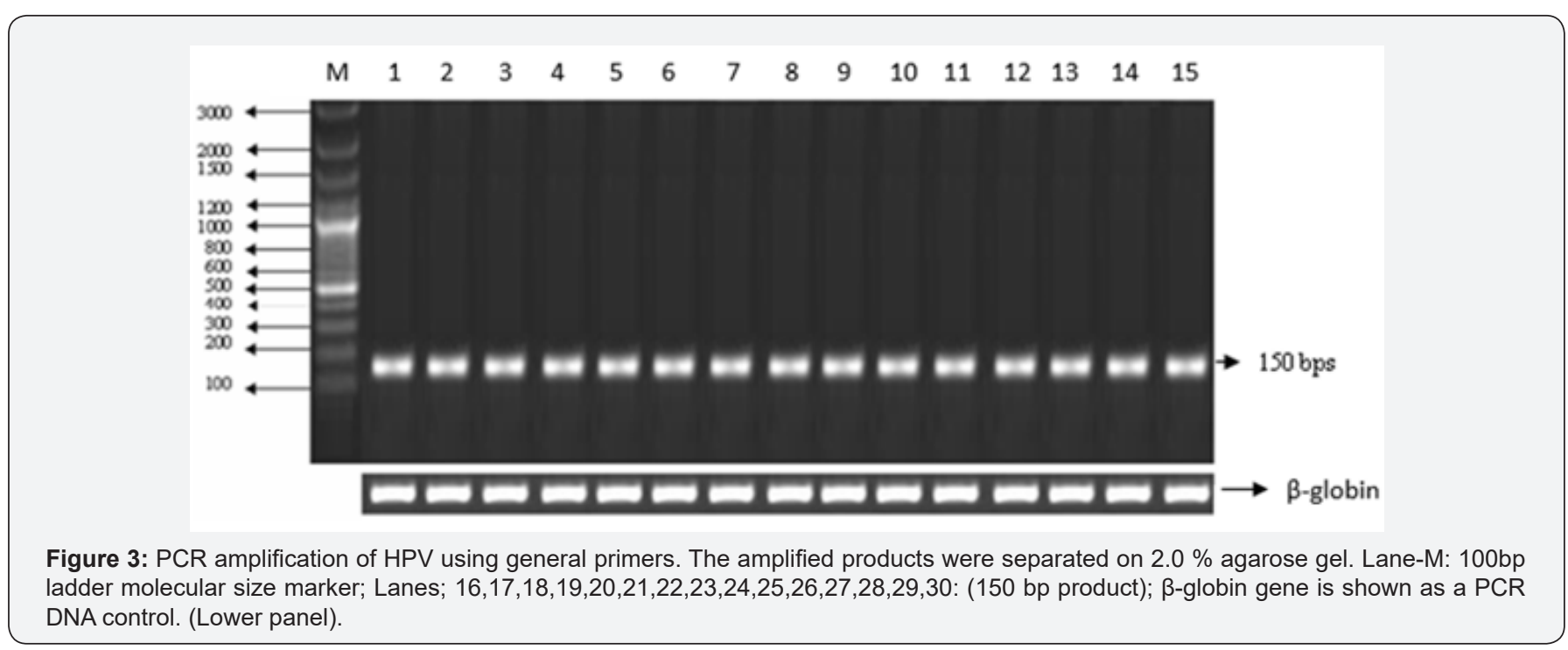

DNA control. (Lower panel)

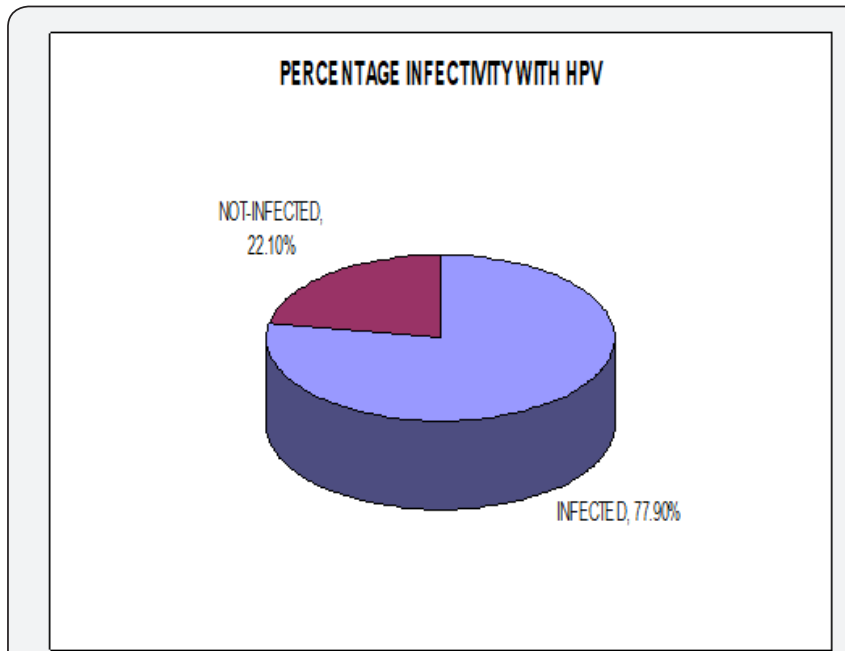

Figure 4: Total Infectivity levels of HPV as determined by compilation of results of both HPV GP PCR assay plus the genotyping assays.

\section{Genotyping for type 16 and 18:}

Out of the total 74 infected patients about 55 (74\%) were infected with HPV type 16 (Figure 5), 3 (4\%) were infected with HPV type 18 (Figure 6), 11 (15\%) had HPV type 16 and 18 coinfection and $5(7 \%)$ were positive for HPV by GP PCR but could not be type specified (Figure 7).

\section{Discussion}

OSCC is normally considered to be linked with tobacco, alcohol and betel/areca nut chewing, however a percentage of patients not genetically predisposed to developing cancer, manage to develop oral carcinogenesis in the absence of all these agents [12-14]. This fact indicates the presence of another etiological agent which can cause cancer independent of these factors. The evidence of presence of viral nucleic acids in OSCC tissue was presented for the first time in 1982, 1983 by Scully C et al. [15]. A meta-analysis by Miller CS \& Johnstone BM performed in 2001 revealed HPV to have been significantly associated with oral cancer as well as 


\section{Advances in Dentistry \& Oral Health}

pre-malignant lesions [16]. The role of HPV in the development of squamous cell carcinoma of the cervix is a well-established fact. Although anatomically distantly located the squamous epithelia of both the cervix and oral cavity have remarkable similarities. The
HPV high risk types found in association with cervical cancer like type 16, 18, 31 and 33 have also found to be associated with the cancerous lesions of the oral cavity as well as the naso-pharynx $[17,18]$.

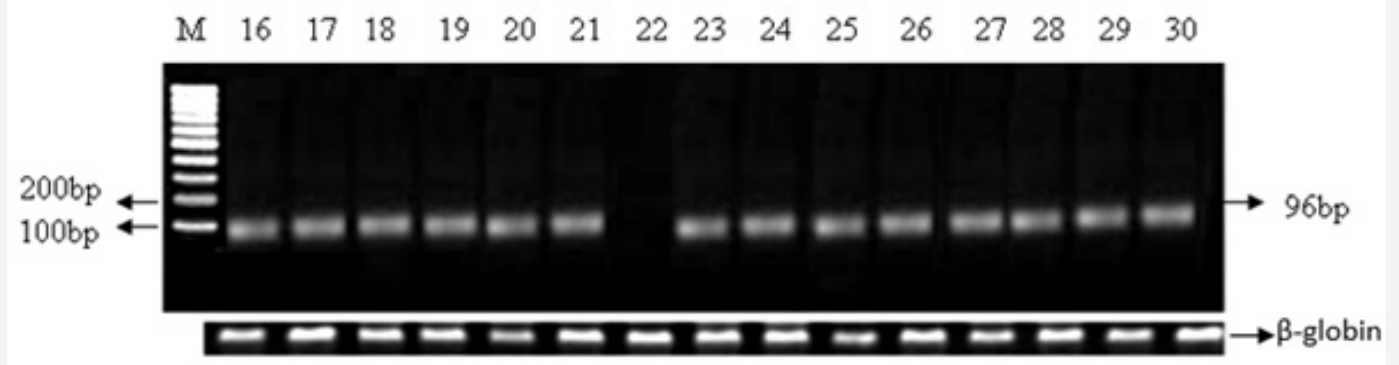

Figure 5: Genotyping for HPV type 16. The amplified products (fragment sized 96bp) were separated on $2.0 \%$ agarose gel. Lane-M: $100 \mathrm{bp}$ ladder molecular size marker; Lanes 16,17,18,19,20,21,22,23,24,25,26,27,28,29,30. (96 bp product); $\beta$-globin gene is shown as a PCR DNA control. (Lower Panel).

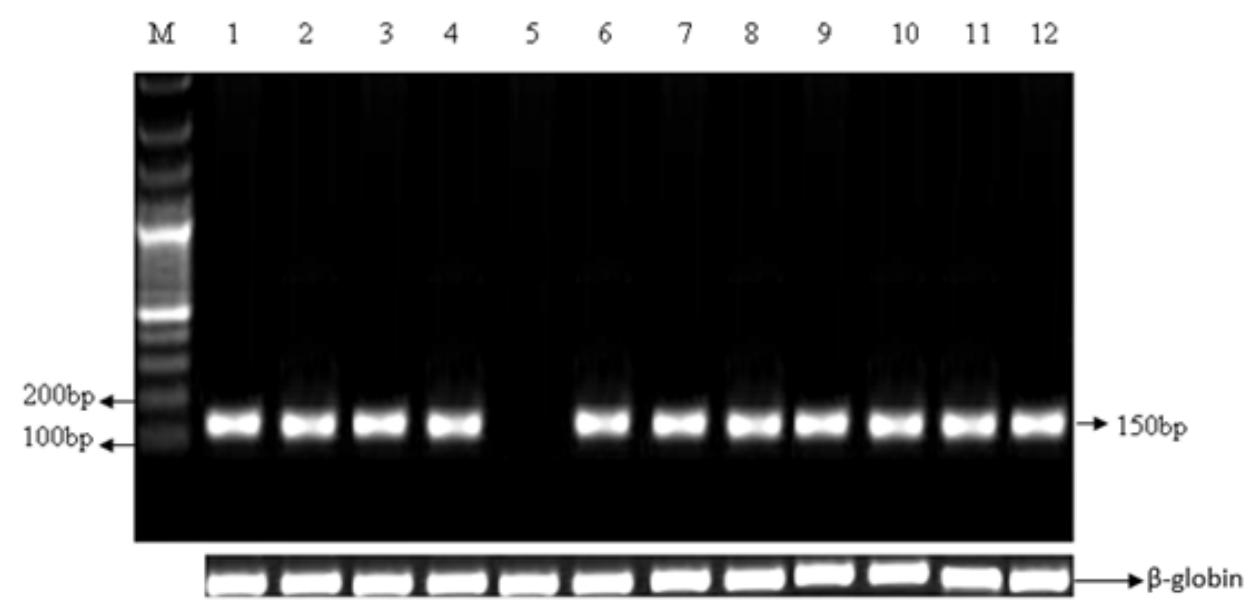

Figure 6: Genotyping for HPV type 18. The amplified products (fragment sized 155bp) were separated on $2.0 \%$ agarose gel. Lane-M: $100 \mathrm{bp}$ ladder molecular size marker; Lane 1: Positive control (human cervical cancer sample previously shown to be positive for type 18). Lanes 2,3,4,6,7,8,9,10,11,12 positive for type 18. (155 bp product) Lane 5: negative for type 18; $\beta$-globin gene is shown as a PCR DNA control. (Lower Panel).

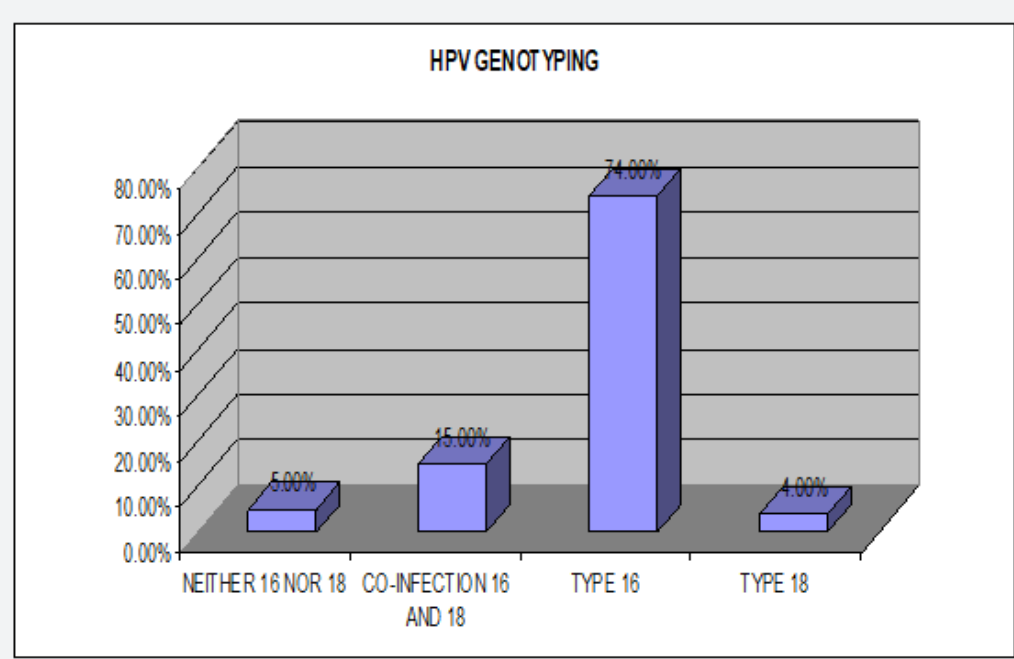

Figure 7: HPV type distribution in study population. 
Table 2: Comparative analysis of HPV infectivity derived from HPV GP PCR assays and the Genotyping PCR assays.

\begin{tabular}{|c|c|c|c|c|}
\hline & \multicolumn{2}{|c|}{ GP PCR } & \multicolumn{2}{c|}{ Total HPV infectivity } \\
\hline & Frequency & Percentage & Frequency & Percentage \\
\hline Positive & 51 & $53.7 \%$ & 74 & 77.9 \\
\hline Negative & 44 & 46.3 & 21 & 22.1 \\
\hline
\end{tabular}

In our study, two methods were employed to determine the presence of HPV. The first one was the histopathological evaluation, in which the morphological changes occurring in the HPV infected squamous cell were observed. This was especially emphasized as more than one third of Pakistani population lives below the poverty line [19], and most of them cannot afford to have PCR analysis done to determine HPV infection. We had a total of 95 samples which were histopathological analysed for the presence of koilocytes, which are HPV infected squamous cells with pyknotic nuclei and a clear halo around the cytoplasm (Figure 1). 50 samples tested positive for the presence of koilocytes out of 95 , which constitutes about $53 \%$ of the total samples. All these 50 samples were later tested positive for HPV infection using GP PCR assays (Table 2).

Histopathological grading of the OSCC samples was also carried out in order to determine the severity of the cancerous process. The histopathological parameters that were observed were the degree of differentiation, cellular atypia, presence of keratin pearls and individual cell keratinizations and degree of dysplasiam. The Table 3: HPV genotype distribution in different types of OSCC. lesions were classified as well differentiated or stage I, moderately differentiated or stage II and poorly differentiated or stage III. In our study we had a total of 49 (52\%) cases of well differentiated squamous cell carcinomas designated as histopathological stage I cancer. 25 (26\%) cases were of moderately differentiated squamous cell carcinoma graded as stage II cancer while 4 (4\%) cases were of the poorly differentiated variety graded as stage III cancer. The most prevalent type of OSCC in our study group was the well differentiated squamous cell carcinoma or stage I cancer, which may represent a trend in patients of Rawalpindi/ Islamabad origin to consult the dentists early on in the cancerous process, which is contrary to the studies done in the rural areas of Pakistan where stage II and stage III cancers are more prevalent, due to lack of easy accessibility to a dentist as well as awareness dearth [20].

Out of these 95 samples 72 were formalin fixed and paraffin embedded, 6 were fresh biopsy specimen unfixed and 17 were endoscopic specimen. In this study group patients ages ranged from 16 years to $86,87 \%$ of the patients were above 35 years of age. The most common anatomic site of involvement was mandible including the tongue area followed by nasopharynx and vocal cords with $23.2 \%(n=22)$ of the patients having carcinoma of the oral cavity that had metastasized to the neck. Around 20\% $(n=19)$ of the cases involved either the buccal or the labial mucosa with $4 \%(n=4)$ showing gingival involvement, while maxillary and palatal involvement was found in $12.4 \%(n=12)$ of the cases.

\begin{tabular}{|c|c|c|c|c|c|c|}
\hline & & \multicolumn{4}{|c|}{ Genotype } & \multirow{2}{*}{ Total } \\
\hline & & Not Present & Both 16, 18 & Type 16 & type 18 & \\
\hline \multirow[t]{8}{*}{ Diagnosis } & Fibroepothelial polyp/SQUAMOUS PAPILOMA & 3 & & 6 & & 9 \\
\hline & Focal dysplasia & & & 1 & & 1 \\
\hline & hyperplasia with chronic infection & & & 3 & & 3 \\
\hline & Keratinized squamous cell carcinoma & 15 & 5 & 27 & 2 & 49 \\
\hline & Moderately differentiated/non Kerat. Squamous cell carcinoma & 6 & 4 & 14 & 1 & 25 \\
\hline & Undifferentiated squamous cell carcinoma & 1 & 1 & 2 & & 4 \\
\hline & Oral submucos fibrosis & 1 & 1 & 1 & & 3 \\
\hline & Verrocus Carcinoma & & & 1 & & 1 \\
\hline Total & 26 & 11 & 55 & 3 & 95 & \\
\hline
\end{tabular}

GP (general primers) based PCR assay was then performed for the detection of HPV. This assay uses primers that have already been reported in the literature [11]. In our study the GP PCR revealed 51 samples (54\%) to be positive for HPV infection while the remaining 44 were HPV free. However, some of the samples that were negative for HPV as tested by GP PCR were determined to be HPV type 16 positive, when genotyped for type specific HPV. In order to reduce human error, this genotyping PCR was repeated thrice in duplicates for the samples that were proven to be negative by GP PCR. The samples positive for type 16 were HPV positive, so a total percentage of infectivity was derived after compiling the data derived from both GP PCR based assay and genotyping assay. The compiled results showed the HPV infected cases to be a total of 74 (78\%) of the 95 OSCC samples (Figure
7), (Tables 2 \& 3), which lies within the range of 25\%-75\% HPV infectivity levels as have been reported by other studies [21,22]. This discrepancy maybe due to mutational changes in the HPV genome in the area previously considered to be highly conserved or the designated area might be comparatively less well conserved in Pakistani origin HPV, as the studies utilizing them have all been based on Caucasian population derived HPV.

When HPV infection and its gender distribution cross tabulations were carried out a very significant association was observed. Out of the 43 females 29 (67\%) were infected with HPV. Similarly, out of 52 males 45 (87\%) were infected. Sex difference among the patients was significantly co-related to HPV infectivity as determined by the Pearson chi square test $(\mathrm{P}=0.02)$, which 
showed a male predilection for HPV infection. This finding may prove to be significant in terms of including anti-HPV vaccination in vaccination regimens for the males, to protect against oral cancer.

Out of the total 74 infected patients about 55 (74\%) were infected with HPV type 16, 3 (4\%) were infected with HPV type 18 $11(15 \%)$ had HPV type 16 and 18 co-infection and 5 (7\%) were positive for HPV by GP PCR but could not be type specified (Figure 7). Type 16 emerged as the most prevalent type of HPV in our OSCC patient population. Type 18 was rare; however, co-infection was observed in 11 cases. All the cases positive for HPV type 18 were malignant, it was not found in the fibro-epithelial polyps that were included in our study. The previous studies have also reported HPV type 16 prevalence over the other types of HPV in OSCC patients' population [23-25]. Different HPV types have also been shown to be variably prevalent because of the geographic differences.

Co-infection was not observed in the HPV infected benign proliferative lesions, the only lesions co-infected were malignant, which may indicate a more aggressive pattern of disease in the case of prevalence of the two high risk types together (Table $3)$. However, a larger co-infected population group needs to be studied in order to derive statistically significant association between co-infection and aggressiveness of the disease. The 5 samples that could not be genotyped for both type 16 and 18 must be infected with some other type of HPV. Cross tabulations of genotyping and sex, age of patients and primary tumour site did not show significant association.

\section{Conclusion}

a. HPV is very prevalent in OSCC patients of Pakistani origin, the prevalence being $78 \%$. Therefore, a significant association exists, and HPV could be the leading cause of oral cancer.

b. HPV type 16 is the most prevalent type of HPV found in association with OSCC patients. Based on this study, serious efforts must be devoted to containing the viral induced oral squamous cell carcinoma.

\section{References}

1. (2018) Head and neck cancers statistics | Cancer Research UK [Internet].

2. Mehrad M, Carpenter DH, Chernock RD, Wang H, Ma XJ, et al. (2013) Papillary Squamous Cell Carcinoma of the Head and Neck. Am J Surg Pathol 37(9): 1349-1356.

3. Maier M, Kraft K, Steinestel K, Schramm A, Lorenz KJ, et al. (2013) Human papillomavirus in squamous cell cancer of the head and neck. A study at the Ulm Military Hospital, Germany. HNO 61(7): 593-601.

4. Liu H, Li J, Diao M, Cai Z, Yang J, et al. (2013) Statistical analysis of human papillomavirus in a subset of upper aerodigestive tract tumors. J Med Virol 85(10): 1775-1785.

5. Neufcoeur PE, Arafa M, Delvenne P, Saussez S (2009) Involvement of human papillomavirus in upper aero-digestive tracts cancers. Bull Cancer 96(10): 941-950.
6. Brebi P, Ili CG, Andana A, Menzel D, Lopez J, et al. (2017) Frequency of Human papillomavirus in women attending cervical cancer screening program in Chile. BMC Cancer 17(1): 518.

7. https://www.nhs.uk/conditions/vulval-cancer/.

8. Giuseppe Micali, MD; Dirk M Elston M. Urogenital Squamous Cell Carcinoma: Overview, Pathophysiology of Penile SCC, Pathophysiology of Prostatic SCC.

9. Waddell KM, Newton R (2007) The aetiology and associations of conjunctival intraepithelial neoplasia: further evidence. $\mathrm{Br} \mathrm{J}$ Ophthalmol 91(1): 120-121.

10. Argyris PP, Kademani D, Pambuccian SE, Nguyen R, Tosios KI, et al. (2013) Comparison Between p16INK4A Immunohistochemistry and Human Papillomavirus Polymerase Chain Reaction Assay in Oral Papillary Squamous Cell Carcinoma. J Oral Maxillofac Surg 71(10):1676-1682.

11. Baay MF, Quint WG, Koudstaal J, Hollema H, Duk JM, et al. (1996) Comprehensive study of several general and type-specific primer pairs for detection of human papillomavirus DNA by PCR in paraffinembedded cervical carcinomas. J Clin Microbiol 34(3): 745-747.

12. Scully C, Field JK, Tanzawa H (2000) Genetic aberrations in oral or head and neck squamous cell carcinoma (SCCHN): 1. Carcinogen metabolism, DNA repair and cell cycle control. Oral Oncol 36(3): 256-263.

13. Scully C, Field JK, Tanzawa H (2000) Genetic aberrations in oral or head and neck squamous cell carcinoma 2: chromosomal aberrations. Oral Oncol 36(4): 311-327.

14. Scully C, Field J (1997) Genetic aberrations in squamous cell carcinoma of the head and neck (SCCHN), with reference to oral carcinoma (review). Int J Oncol 10(1): 5-21.

15. Scully C, Prime S, Maitland N (1985) Papillomaviruses: their possible role in oral disease. Oral Surg Oral Med Oral Pathol 60(2): 166-74.

16. Miller CS, Johnstone BM (2001) Human papillomavirus as a risk factor for oral squamous cell carcinoma: A meta-analysis, 1982-1997. Oral Surg Oral Med Oral Pathol Oral Radiol Endod 91(6): 622-635.

17. Tulay P, Serakinci N (2016) The role of human papillomaviruses in cancer progression Quick Response Code. J cancer Metaste Treat 2: 201-213.

18. Xavier SD, Filho IB, Lúcia C, Lancellotti P (2005) Prevalence of histological findings of human papillomavirus (HPV) in oral and oropharyngeal squamous cell carcinoma biopsies: preliminary study Summary. Rev Bras Otorrinolaringol 71(4).

19. Kausar S, Qureshi R (2005) Short Communication Poverty in Pakistan: A Socio-Economic Survey of Punjab. Journal of Agriculture \& Social Sciences 1(2): 204-205.

20. Zaidi SMA, Manzoor NFAS (2010) The challenge of head \&amp; neck squamous cell carcinoma control in Pakistan. J Pakistan Med Assoc 60(8): 703-704.

21. McKaig RG, Baric RS, Olshan AF (1998) Human papillomavirus and head and neck cancer: epidemiology and molecular biology. Head Neck 20(3): 250-265.

22. Miller CS, White DK (1996) Human papillomavirus expression in oral mucosa, premalignant conditions, and squamous cell carcinoma: a retrospective review of the literature. Oral Surg Oral Med Oral Pathol Oral Radiol Endod 82(1): 57-68.

23. Gillison ML, Koch WM, Capone RB, Spafford M, Westra WH, et al. (2000) Evidence for a causal association between human papillomavirus and a subset of head and neck cancers. J Natl Cancer Inst 92(9): 709-720.

24. Bogusiak K, Kobos J (2014) The role of human papillomavirus infection in the head and neck region and methods for its detection. J pathol 65(1): 1-14. 
25. Balaram P, Nalinakumari KR, Abraham E, Balan A, Hareendra NK, et al (1995) Human papillomaviruses in 91 oral cancers from Indian betel

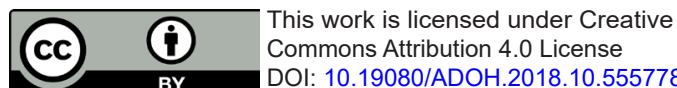

DOI: $10.19080 / A D O H .2018 .10 .555778$ quid chewers--high prevalence and multiplicity of infections. Int J cancer 61(4): 450-454.

\section{Your next submission with Juniper Publishers will reach you the below assets}

- Quality Editorial service

- Swift Peer Review

- Reprints availability

- E-prints Service

- Manuscript Podcast for convenient understanding

- Global attainment for your research

- Manuscript accessibility in different formats

( Pdf, E-pub, Full Text, Audio)

- Unceasing customer service

Track the below URL for one-step submission https://juniperpublishers.com/online-submission.php 